Pages: 91-107

\title{
Understanding the uncomfortable kōkako: the challenge of applying threshold concepts in Māori studies
}

\author{
Dr Meegan Hall (Ngāti Ranginui) \\ Victoria University of \\ Wellington \\ Peter Adds (Te Atiawa) \\ Victoria University of \\ Wellington \\ Dr Mike Ross (Ngāti Hauā) \\ Victoria University of \\ Wellington \\ meegan.hall@vuw.ac.nz \\ peter.adds@vuw.ac.nz \\ mike.ross@vuw.ac.nz \\ Phillip Borell (Ngāti Ranginui) \\ University of Canterbury \\ Phillip.borell@canterbury.ac.nz
}

\begin{abstract}
There are Māori studies ${ }^{1}$ programmes in all eight New Zealand universities and thousands of Māori studies students enrol each year. However, little research has been done on the scholarship of teaching and learning (SOTL) within the Mãori studies discipline. This article investigates, through the process of an integrative literature review, the potential to apply the theory of threshold concepts (Meyer \& Land 2006) - the idea that there is a set of transformational concepts that can unlock understanding in any discipline - to the Mãori studies discipline. It highlights issues that arise in applying threshold concepts to a relatively new discipline that centres Indigenous knowledge and practices. The transformative elements of Māori studies and the irreversible change that Western epistemologies have caused to Māori studies' knowledge are discussed. The bounded aspect of Māori studies is canvased, as well as the ability of Māori studies to integrate with other cognate disciplines. The troublesome nature of Māori studies content is explored, along with the discursive elements of its formal and coded curricula. Also, the idea of liminality is examined, as a way to demarcate the academic territory of Māori studies and clarify the curriculum. Ultimately, many questions emerge in this article but also opportunities to advance the SOTL research in both threshold concepts as a theory and Māori studies as a discipline.
\end{abstract}

1. Māori studies is a subject of study taught in New Zealand universities. It is offered at undergraduate and postgraduate level and at various universities students can complete an entire degree in the subject, and/or a major or minor. Topics covered include Māori language, culture and society - both past and present. Māori studies is equivalent to other native studies and indigenous studies programmes taught in universities elsewhere in the world. 


\section{ABSTRACT (Māori language)}

Kei ngā Whare Wānanga Pākehā e waru ngā hotaka Māori motuhake e tū ana. $\bar{A}$, i ia tau ka puta te tini o ngã tauira Māori i aua tari. Engari, he ruarua noa iho te rangahau i ngā paepae akoranga hei ekenga mō ngā tauira whai mātauranga Māori ai. Ka whakatewhatewha tēnei pānui i aua paepae akoranga (threshold concepts) me ōna hononga ki te whakaakoranga mātauranga Māori. Ka kōrerohia ngā take i puta mai i te whakamahi o ngā paepae akoranga me te arotake ki ngā mātauranga o ngā iwi taketake. Ka wānangahia te mauri o te mātauranga Māori me te pānga mai o ngā mātauranga nō iwi kē. E whakaatu ana i ngā kōpikopikonga i te ara whai mātauranga ōkawa, ōpaki rānei. Waihoki, he mea tohu atu te takiwā tūturu o te mātauranga Māori me ētehi ara ako i ngā tari Māori. Te mutunga iho, he pātai he wero he kōwhiringa hei kōkiri i te rangahau mātauranga paepae akoranga me te whakamārama ake i ētehi tino āhuatanga e hāngai pū ana ki te akoranga mātauranga Māori.

\section{Introduction}

Māori studies was once labelled the "uncomfortable science" (Mead 1983:345; Walker 1999:197) because of the tensions that surrounded its existence within the academy. It has also been described as a kōkako, a species of the New Zealand wattlebird with a haunting, powerful song (Mead 1983:337). In the early years of the Māori studies discipline, non-Māori scholars accused it of lacking academic rigour or a body of literature (Mead 1997:43; Reilly 1996:395 \& 2008:1). Today, there are Māori studies programmes in all eight New Zealand universities and thousands of Māori studies students enrol each year. However, little research has been done on the scholarship of teaching and learning (SOTL) within the discipline. This article seeks to investigate, through the process of an integrative literature review, the potential to apply the theory of threshold concepts (Meyer \& Land 2006) - the idea that there is a set of transformational concepts that can unlock understanding in any discipline to the Māori studies discipline. It highlights issues that arise in relation to applying threshold concepts to a relatively new discipline that centres Indigenous knowledge and practices. Juxtaposing the 'uncomfortable kōkako' in the title of this article serves to foreshadow the many SOTL challenges, and the potential, of applying the theory of threshold concepts to Māori studies.

Māori studies emerged as a subject of study in universities in the 1950s but, today, there is still a need to develop it further as a discipline, to identify and articulate effective Māori studies pedagogies and to produce high-quality Māori studies graduates (Hall, Rata \& Adds 2013:2). As a discipline, it exists in powerful defiance against a history of colonisation and state-sanctioned assimilation and integration, and is a symbol of Māori rangatiratanga (autonomy). However, only brief histories of Māori studies have been written (Durie 1996; Mead 1983 \& 1997; Pohatu 1998; Reilly 2011; Smith 2002; Walker 
1999; Webster 1998) and the literature about the Māori studies curriculum is piecemeal at best. Also, the place of Māori studies in universities is challenged by the re-emergence of tribal wānanga (Māori places of higher learning) and by the proliferation of Māori topics being taught within other disciplines (Reilly 2008). Globally, there are calls for Indigenous programmes to be "mainstreamed" (Gaudry 2017). Thus, by taking time to reflect on the opportunities and challenges that arise in the application of threshold concepts, this article will make a much-needed contribution to the developing SOTL in Māori studies.

\section{Integrative literature review process}

This article is based on an integrative literature review. It seemed appropriate because these reviews are designed to combine the literature to make a critical, theoretical or conceptual stand on what is currently understood but perhaps not well integrated. They are particularly useful when little has been written or if the area is one of emerging knowledge. In this case, the published material on Māori studies, particularly in relation to threshold concepts, is under-developed and fragmented and needs explication to draw attention to areas of new focus.

To develop this review, the authors followed the guidelines provided by Torraco (2005) to ensure that it was robust and consistent with good practice. According to Torraco (2005:363), one form of synthesis from integrative literature reviews is to create "a research agenda that flows logically from the critical analysis of the literature. The research agenda should pose provocative questions (or propositions) that give direction for future research". For this project, the authors sought to critically analyse Māori studies literature and examine whether further research into threshold concepts in Māori studies was needed, and what challenges it might encounter.

The review began with an online search for literature using the search term 'Māori studies'. The search was intentionally kept very broad because the authors were aware that there was not likely to be much published material on this topic. Somewhat surprisingly, the initial search identified 3420 potential sources but the vast majority were simply related to the biographical data of the publications' authors. Eventually, only 31 sources were found to be relevant to this research topic. In addition, the bibliographies of the 31 sources were checked in order to identify any other publications that may not have been identified through the online search, and this uncovered a further four relevant publications.

Once the sources had been found, their bibliographic records were entered into a synthesis matrix that had been developed for this article. The matrix process provided a way for the authors to read and organise any useful excerpts and ideas into various emerging themes. It also allowed the authors to note their personal reflections and critiques of the literature as they worked through the material, and preserve it for later write up. At the end of the matrix process, all 35 Māori studies sources had been scoured and synthesised to enable a review of the opportunities and challenges for threshold concepts in Māori studies that are raised in this article.Threshold concepts and SOTL

The notion of threshold concepts intersects with the SOTL arena in a number of ways. As the body of work about SOTL has grown and developed, threshold concepts have been identified as part of the second wave of SOTL literature (Gurung \& Schwartz 2010). Some have used threshold concepts as a lens through which to examine SOTL more closely (Simmons et al. 2013; Webb 2016). Others have 
seen threshold concepts as a way to engage people in the process of SOTL (McLean 2009; O'Brien 2008). The idea has resonated with many SOTL scholars that there are threshold concepts within every discipline that students new to the subject need to acquire in order to successfully advance their learning (e.g. Azam 2012; Cowart 2010; Khan 2014).

The originators of the theory were quick to establish a list of characteristics that they claimed set threshold concepts apart from other concepts. Meyer and Land (2006:3) explained that "threshold concepts can be considered as akin to a portal, opening up a new and previously inaccessible way of thinking about something" and that this 'portal' could be identified by the following traits:

- Transformative - i.e. it precipitates a "significant shift in the perception of a subject"

- Irreversible, probably - i.e. it is "unlikely to be forgotten" or unlearned

- Integrative - i.e. it reveals the interconnectedness of information

- Bounded, possibly - i.e. it delineates a new conceptual area

- Troublesome, potentially - i.e. it is difficult for students to acquire, which adds to its significance (Meyer \& Land 2006:7-9).

Meyer and Land (2006) later added two more features to the list:

- Discursive - i.e. it requires "new and empowering forms of expression" (2006:20)

- Liminality - i.e. it involves crossing a liminal state, a "rite of passage" (2006:22).

Land and Meyer (2010) have also emphasised the ability for threshold concepts to not only change the way learners understand a subject but to affect a change within the learners themselves. It is this way of thinking about threshold concepts that most resonates with the context of Māori studies. However, Meyer and Land do not appear to have considered something that commonly occurs in Māori studies - when huge, but different, ontological shifts occur in Māori and non-Māori students when they learn about Māori history and oppression (Te Huia 2016). This requires further research.

Since Meyer and Land's initial articulation of the threshold concepts theory, some scholars have attempted to refine or clarify certain aspects. Barradell and Peseta (2014) noted that threshold concepts can be about more than just new ways of thinking, and can include changes in skills, attitudes and behaviours. Talanquer (2015:3) suggested a re-emphasis on "conceptual thresholds" to accentuate "the cognitive elements and processes that support the construction of a threshold concept and use the metaphor of "crossing a conceptual threshold" to signify the acquisition or development of such elements". Both suggest that the theory of threshold concepts can be further refined.

Others have been outright critics of threshold concepts, highlighting its limitations. Rowbottom (2007:267) highlighted how the degree of transformation that a student experiences is more likely to relate to their pre-existing knowledge rather than the concept itself. This point relates to Māori studies - for example, a transformative concept for a non-Māori student may not be one for a Māori student. It suggests that perhaps the theory of threshold concepts does not account for learner diversity. Ultimately, the application of threshold concepts within Mãori studies is likely to highlight strengths and weaknesses within the theory, some of which have already been indicated in threshold concepts work undertaken in the field of Indigenous studies. 


\section{Threshold concepts and Indigenous studies}

The relevance of threshold concepts to Indigenous studies has been highlighted in a recent framework developed at the University of the Sunshine Coast for incorporating Aboriginal and Torres Strait Islander knowledge into the university curriculum (USC 2016:2). Threshold concepts theory was also successfully applied in the development of Indigenous digital teaching resources for a nurse education programme (Levett-Jones, Bowen \& Morris 2014). However, already, the definition of threshold concepts has raised some questions for people wanting to apply it to Indigenous studies. For example, to whom should the knowledge be troublesome? Presumably it is meant to be troublesome for the novice learner but some Indigenous or Māori studies concepts are more troublesome to nonIndigenous/Māori students than Indigenous/Māori students. So, from whose perspective is the 'troublesomeness' measured? Scholars working in Indigenous studies around the world have raised these and other questions about threshold concepts. Susan Page is the leading Indigenous Australian academic to engage with threshold concepts in this context. As a Professor in Indigenous Studies, she has written and spoken about the multidisciplinary foundation of her field and its emerging disciplinary state (Page 2014a). Her ongoing work draws on the threshold concepts notions of liminality and troublesomeness to explore the reasons why Indigenous and non-Indigenous students encounter challenge in their learning (Page 2016).

Page has also emphasised the impact of enrolling a high proportion of non-Indigenous students in Indigenous studies, with their needs often taking priority (Page 2014a:24). This can be to the detriment of Indigenous students. A similar enrolment pattern exists in first year Māori studies courses. While this may be a potential challenge for identifying threshold concepts, it could be ameliorated somewhat by what Barrett et al. (2016:141) describe as the potential for threshold concepts to reconstitute student identities. They suggest that threshold concepts can affirm what students know internally, such as in the case of Indigenous students engaging in learning around Indigenous studies.

Finally, a number of authors have drawn connections between the notion of liminality (in relation to threshold concepts) and Nakata's (2007) idea of the 'cultural interface'. Page (2014b:1) highlighted this overlap within Indigenous studies, which she says is exemplified in the "contested space between Indigenous and non-Indigenous knowledge systems". She argues that non-Indigenous students who enrol in Indigenous Studies programmes may encounter the double challenge of entering both a liminal space and a cultural interface (Page 2015). This point is expanded further by Snepvangers and Bulger (2016:4) who applied the idea of liminality to the "dilemma" of delivering Indigenous studies programmes within the construct of a Western university setting. Together, these authors suggest that Indigenous theorising about the challenge of working at the 'cultural interface' both resonates with and adds to the notion of threshold concepts that operate in a liminal space. Clearly, Māori studies provides a strong example of a discipline operating in just such a space.

\section{The emergence and purpose of Māori studies}

The academic discipline of Māori studies is based on the culture and language of the Indigenous Māori people of New Zealand. Today, Māori make up 15\% of the New Zealand population (Statistics New Zealand 2015) but a high birth rate and lengthening life span is resulting in a growing Māori community. The East Polynesian ancestors of the Māori people arrived in New Zealand circa 1350AD 
(Anderson, Binney \& Harris 2014). Since that time, Māori have engaged in higher education, initially through tribal wānanga and then later in universities and other tertiary education providers. Initially, in the late 1800s, Māori enrolments in New Zealand university study were low (Durie 2009:2-3) but now Māori have the highest participation rate in tertiary education of any ethnic group in New Zealand and Māori students made up almost 20\% of all tertiary enrolments in New Zealand in 2014 (Education Counts 2015). Many of those Māori students choose to learn about their own cultural histories, practices and languages by enrolling in Māori studies degrees.

Despite this long history of Māori engagement in higher education, Māori studies was slow to emerge as a topic of university study. New Zealand's Governor Grey was reported in the New Zealand Herald in 1885 as saying that Polynesian languages should be part of the university curriculum (Smith 2002:16) but it took until 1908 for two Māori politicians and scholars, Sir Apirana Ngata and Te Rangihiroa Peter Buck, to officially raise the idea of teaching Māori subjects at university level (Sorrenson 1986:83). In 1928, despite their misgivings over a perceived lack of teaching literature, the University of New Zealand Senate approved the Māori language to be an examinable subject for the Bachelor of Arts degree (Mead 1983:335; Sorrenson 1986:83). According to Reilly (2011:340), first year 'Māori' courses were offered at the University of Auckland from 1928 but it took a further 24 years for 'Māori studies' courses to be established (Durie 1996:22; Mead 1983:337; Reilly 2008:3 \& 2011:340). This coincided with the establishment of a department of Māori studies at the University of Auckland in 1952 (Timms 2007:5), which itself was a significant milestone, predating as it did the emergence of women's studies, Black studies and Native studies programmes in North America (Smith 2000:44).

Other New Zealand universities eventually followed suit, in keeping with a national Māori cultural revival that swelled in the 1960s and led to the increased teaching of Māori culture in early childhood, primary and secondary education as well (Stewart-Harawira 2013:42; Sissons 1995:63; Webster 1993:225). Victoria University of Wellington began to offer Māori studies courses in 1966 (Durie 1996:22), and appointed the first professorial Chair in Maori studies in 1975 (Mead 1983). The University of Waikato began offering Māori studies courses in 1968 (Smith 2002:236) and Massey University in 1972 (Webster 1998:157). The South Island universities eventually followed their North Island counterparts; the University of Canterbury began teaching a graduate programme in Māori studies in 1984, Lincoln University split from Canterbury in 1990 and established their own small Māori studies programme soon after, and the University of Otago began teaching Māori language courses in 1981 before appointing their first permanent Māori studies lecturer in 1986 (Reilly 2008:3; Webster 1998:157). By the time Auckland University of Technology, the eighth and newest New Zealand university, was established in 2000 (AUT timeline), Māori studies was firmly located within the New Zealand academy and there was no question about its inclusion within the new institution's offerings.

While the dates and chronology of the establishment of Māori studies courses and departments is telling, so too is the process from which the various Māori studies programmes emerged. For the first three decades of its existence, Māori studies was considered by many academics within New Zealand universities to simply be a 'child' of another more established discipline (Mead 1983) - although the disciplinary 'parent' varied depending on the university. The primary disciplinary 'homes' have been attributed to anthropology (Mead 1983; Stewart-Harawira 2013) and linguistics (Durie 1996), but others featured too. At the University of Auckland, the disciplinary 'parent' of Māori studies was 
perceived to be anthropology (Openshaw 2006; Smith 2000 \& 2002; Webster 1998), and the 'father figure' was thought to be a Pākehā (non-Māori New Zealander), Professor Ralph Piddington (Openshaw 2006:114; Webster 1993:228). In fact, Piddington's anthropology influence had a wide impact on Māori studies, as many of his graduates went on to hold key academic roles in Māori studies programmes around New Zealand. Mahuta at the University of Waikato, Mead at Victoria University of Wellington, Kawharu at Massey University, and Hohepa and Walker at the University of Auckland had all studied under Piddington at Auckland.

Despite Piddington's support and advocacy for the establishment of Māori studies at Auckland, initially at least, "Maori Studies as a subject was not seen to be separable from anthropology nor worthy of a place in its own right" (Sorrenson 1982:17). Even Mead's reference to Māori studies as the uncomfortable science harks back to its disciplinary connections to anthropology, the original 'uncomfortable science' (Mead 1983:345). The process of moving beyond the shadow of anthropology was a long one, taking 40 years for Māori studies to attain independence from anthropology at the University of Auckland in 1991 (Smith 2002; Walker 1999).

At Victoria University of Wellington too, Māori studies was at first taught out of anthropology and, even after their Māori studies department gained independence, some still expected it to stay within anthropology's theoretical and methodological boundaries, and others questioned its academic credibility (Durie 1996; Walker 1999). One reason given at the time was that Māori studies had not arisen from an "open, distinctive discipline" and, instead, it was expected that Māori material would be dispersed across other established disciplines (Durie 1996:23). In their recent research about the experiences of Māori academics, Mercier, Asmar and Page (2011) found that these criticisms of Māori studies not being a 'proper' academic discipline still lingered.

Massey University also initially cast Māori studies as a subset of anthropology, appointing Sir Hugh Kawharu to an anthropology chair in 1970 to develop their first Māori courses. It took until 1986 for Professor Mason Durie to become a Māori studies professor and for Māori studies to become a separate department at Massey (Walker 1999:195). Durie (1996:23) later explained that confining Māori studies within established disciplinary boundaries was, in his view, "both ideologically and politically unsound, and academically untenable". Salmond (2003:23) described this position as a resistance to being 'othered' by the Euro-American 'eye' of anthropology.

In contrast, at the University of Otago, Māori studies developed from the linguistics programme (Timms 2007:5) and at the University of Canterbury and the University of Waikato the subject of Māori studies emerged from within their German programmes (Mead 1983:350; Timms 2007:5). This language focus within Māori studies is not surprising, given the reverence in which the Māori language is held within Māori communities. In fact, the Māori language was also a prominent part of the Māori studies programme at the University of Auckland, where the first dedicated lecturer of Māori language, Bruce Biggs, prided himself on his adherence to the methodologies of linguistics, which he considered a 'real discipline' (Smith 2002:229).

The history of the emergence of Māori studies is relevant to the question of how threshold concepts may apply within Māori studies. As a relatively young university subject, Māori studies is still evolving and developing (Smith 2000:44), which begs the question, how developed does a discipline need to 
be in order to identify threshold concepts? Critics may contend that it has not had sufficient time or cohesion to embed key theories or methods, which in turn may bring into question the reliability and appropriateness of identifying its threshold concepts. They may also suggest that the anthropological origins of Māori studies have had a huge influence on the field's purpose and curriculum and therefore, potentially, its threshold concepts. Māori studies has, however, developed the more "authentic Māori scholarship" that Durie (1996:23) once longed for, including a foundation of kaupapa Māori theory and methodology (Ka'ai 2000; Royal 2012:31) and an extensive body of literature that informs the discipline. Whether that has resulted in an established core curriculum, with identifiable threshold concepts, is worthy of further investigation.

\section{The Māori studies curriculum}

Over the years, Māori studies academics have intermittently met as a collective to discuss the issues surrounding the teaching and research of their subject (Mead 1983:333). However, despite this intention to collaborate, each university has essentially developed its Māori studies curricula in isolation. While Māori studies is seen by many as the core repository of Māori knowledge in universities (Mercier et al. 2011:87), others have criticised it for not defining what is unique to the discipline and worthy of continuation (Smith 2002:318). This lack of definition may limit the ability to identify threshold concepts that apply universally across the Māori studies discipline.

Most Māori studies commentators agree that there are two parts to the Māori studies curriculum, the Māori language and the Māori culture (Biggs 1978:5; Durie 1996; Hall, Rata \& Adds, 2013:1-2; Mead 1983:333; Pohatu 1998; Reilly 2008 \& 2011; Smith 2002; Timms 2007; Walker 1999; Webster 1998). The language part of the curriculum is relatively clear; students are expected to learn the Māori language, mostly through exposure to linguistic formulae and lots of practice, and achieve a level of oral fluency (Smith 2002:231). The culture component is less straightforward. Initially, courses about Māori customs, attitudes and values attempted to rebut the assimilationist practices of the past (Webster 1998). Then, in the 1980s, a shifting 'culture' curriculum merged Māori and Western styles of learning (Salmond 1983:327) and focused on "prehistory, traditions, tribal histories, art, oratory and customary concepts" (Mead 1983:333). Walker (1999:193) similarly thought the culture element of Māori studies should focus on the cultural practices of the past, citing kawa (marae protocol), whaikörero (oratory), waiata (songs and chants), mythology, tribal traditions, whakairo (carving), tukutuku (decorative fibre work) and raranga (fibre weaving) as suitable 'culture' topics. While Durie (1996:21) agreed that Māori language study should remain at the core of Māori studies, he suggested that from the 1990s Māori studies needed to focus more on Māori social, cultural and economic development and engage in developing Māori centred methodologies, philosophies and theoretical paradigms. Walker also advocated for a stronger ethnic political stance (Webster 1998:176) that focused on tino rangatiratanga (Māori sovereignty), the Treaty of Waitangi, tribal land claims and the post settlement phase of Māori development (Walker 1999:197).

Today, there is no uniform curriculum within Māori studies across New Zealand. Māori studies courses span a heterogeneous range of topics, from Māori politics to psychology, science to law, and address issues facing Māori and other Indigenous peoples (Timms 2007). However, scholars have alluded to potential threshold concepts that arise from a Māori philosophy that is interwoven across the curriculum (Smith 2000:43). Concepts such as whakapapa (genealogy) (Mead 1983:343), 
rangatiratanga and marae (Māori community complexes) processes (Walker 1999) are all points for further investigation.

A related point is the influence that Māori tribal groups have had on the development of the Māori studies curriculum. Tribal regionalism has affected each of the Māori studies programmes, as evidenced by the strong influence of Ngāi Tahu at the Universities of Otago, Canterbury and Lincoln, Ngāti Whātua and the tribes of Te Taitokerau at the University of Auckland (Webster 1998), and the Tainui people at the University of Waikato. The academic personnel also dictated curriculum development. Biggs' presence at Auckland meant that the programme had a strong linguistics influence, Karetu at Waikato brought a strong focus on oral language development, and Mead at Victoria built a strong material culture focus (Smith 2002:237). This raises an interesting point about the place-based education that occurs in Māori studies - how does that relate to the idea of threshold concepts? Is there a University of Canterbury approach, for example, that makes it different from a Victoria University approach to Māori studies, and is that in some way based on connections to people and place?

In an added twist, Smith (2002:16) argues that since the Māori studies curriculum was actually informed by knowledge held within Māori communities, universities are simply kaitiaki (guardians) of that knowledge. However, she suggests that Māori studies has reframed the Māori knowledge so that it can be 'knowable' within a university context. She raises an interesting point. In turning Māori studies into a university subject, has the Māori knowledge been somehow changed in order to make it knowable? This is an idea that has been debated within Indigenous studies too. Nakata (2006:267) raised similar concerns when he asked:

What does it mean then, for an Indigenous academic to participate in the continuing production of knowledge about Indigenous people, from within the academy, when our goals and commitment are to serve our own people, to rebuild communities and their futures? What does it mean for our participation in the continuing production of knowledge in Indigenous Studies, if what we do, if our Indigenous perspectives, knowledge and analysis are inscribed in and through Western ontology and circulate back to shape practice in Indigenous contexts in similar ways to Western production?

In relation to the idea of identifying the threshold concepts in Māori studies, it would seem that it is not just the concept that is a 'threshold' but perhaps the way of knowing too.

Finally, it is clear that the curriculum of Māori studies is about more than the transmission of Māori knowledge. It is also about the cultural survival of the Māori people (Hall, Rata \& Adds 2013:1), providing a process for decolonisation (Smith 2000:44), reclaiming and rediscovering Māori cultural identity (Firth 2003:140) and resisting the prevailing Pākehā ideologies that dominate New Zealand education (Ka`ai 2000:1). The drive to teach Māori studies students to speak Māori comes not from mere disciplinary interest but the need to save the language from extinction (Mead 1983). The motivation to teach about the Māori culture comes from a need to "put back into Maori minds, hearts and souls those things that were psychologically bruised in earlier generations" (Dewes 1975:66). The idea of claiming space for Māori in universities is important for the support it gives to cultural revitalisation. For the most part, other disciplines have used threshold concepts to gain clarity around the learning process. For Māori studies, threshold concepts could be as much about marking academic 
territory as it is about clarifying the curriculum. Perhaps the articulation of threshold concepts can support the Māori studies claim for space in the academy?

\section{Applying threshold concepts to Māori studies}

During the course of this review, a number of challenges emerged around the application of the threshold concepts theory within Māori studies. One question that arose is whether the global connection between Māori studies and other critical, ethnic or cultural studies programmes can (or should) influence its threshold concepts. The emergence of Māori studies in New Zealand has been described as a microcosm of the way that cultural studies developed within the academy (Walker 1999:187). It contributed to the survival of an Indigenous people, preserving their knowledge systems and languages and maintaining their spiritual connections with the environment and other communities (Smith 2002:27). Nakata (2006:267) writes about the way that Māori studies and Native American studies both contributed concepts, theories and methodologies to Indigenous studies, emphasising the cross-disciplinary nature of such fields. Likewise Mead (1997:43) writes of Māori studies developing alongside native studies, black studies, and indigenous studies and how it "reflects the need of various indigenous groups to make the university systems work for them and to use the resources, skillls and status of the institution to give a better understanding of and respect for the cultures of the native peoples". Teaiwa (2001:347) takes the question even further, asking what the difference is between Hawaiian studies, Pacific studies or Māori studies? She boldly queries whether the differences are simply geographic, political, methodological or philosophical. With such strong similarities being noted in the literature, should there also be an affinity or uniformity to the threshold concepts across these disciplines too?

Setting aside for a moment the complexity of connecting with other Indigenous, cultural or ethnic studies elsewhere in the world, another question that arose from the literature is whether threshold concepts theory can accommodate the multi-, inter- and transdisciplinary nature of Māori studies. Durie (1996:24) suggested that Māori studies has the potential to "bring disciplines together" and transcend disciplinary constraints. Mead (1983:345) also saw no boundaries for Māori studies, and advocated for Māori studies scholars to draw on theories and methods from other disciplines. Coincidentally, some Māori studies scholars have described this as being in a liminal position (Reilly 1996:406), with Māori studies crossing thresholds into other disciplines. Over time, this kind of interdisciplinarity has become the norm in Māori studies. For example, Māori studies routinely offers Māori science courses that "bridge the philosophical gap between Western science and Indigenous knowledge" (Mercier et al. 2013:125). What impact does this have on the parameters of Māori studies? Where are the edges? And what does this mean for identifying its threshold concepts? This confusion over the way to handle the interdisciplinary aspects of Māori studies may prove a challenge for identifying the threshold concepts.

While Mead was in favour of drawing on other disciplines within Māori studies, he also saw how other disciplines had hindered the development of Māori studies. He described an ethnocentric approach, which meant, "that every subject area or discipline within, say, a university has its slice of the Maori cake. Thus, anthropology often has Maori within it, history has a strong interest in Maori land and Maori leaders, education in the pedagogy of the Maori minority, medicine in Maori health and so on" (Mead 1983:337). Durie (1996:22) also described Māori studies as "somewhat uncomfortably" being 
both a discipline in its own right, and a component of every other New Zealand university subject. Reilly (2008) coined this as the mauri Māori within the academy, the Māori life force that seeps into other disciplines. It presents a challenging curricular conundrum, however, this may also indicate that mauri could be a threshold concept of Māori studies.

While, as noted earlier, the various Māori studies programmes across New Zealand have been led almost exclusively by Māori scholars, there is no doubt that non-Māori views and people have impacted on the development of the discipline. Non-Māori staff are employed in Māori studies teaching programmes and thousands of non-Māori students fill Māori studies classes every year (Hanson 1989). Non-Māori scholars have helped reframe Māori language and knowledge to be 'knowable' from Western epistemologies (Smith 2000:45). Non-Māori colleagues from outside of Māori studies have also attempted, over the years, to dictate what is (or is not) taught in the programmes (Reilly 1996:395; Walker 1999:193). At one time, Māori was even defined within New Zealand universities as a 'foreign language' (Smith 2002:216), despite being Indigenous. So, how does the impact of non-Māori people on Māori studies affect the curriculum, and therefore the threshold concepts? Smith (2000:50) suggests that, as a reaction to this non-Māori 'interference' and inability to understand Māori ways of knowing, Māori have developed a metaphorical 'separate space' in which to be Māori. She describes the emergence of a 'visible' Māori studies discourse and a separate set of coded concepts and ways of knowing that sit "outside the bounds of belief according to Pakeha epistemologies" (Smith 2002:50). Pohatu (1998:163), in a similar vein, explains how Māori studies straddles the "the social academic world and the natural Maori world - precipitating a split academic/cultural personality". This belief in Māori ways of understanding the world that do not conform with Western ideologies has been criticised in the academy (Webster 1998) but has nevertheless developed and strengthened over time. It suggests a potential need for two sets of threshold concepts for Māori studies, one for the non-Māori institution and learners and another for Māori. But, can the theory of threshold concepts even apply to the 'outside the bounds' set? And, is there an inherent tension between identifying the threshold concepts (in order to help Māori studies become more knowable) and the idea of keeping Māori studies less knowable to those not meant to know?

One final challenge relates to the emergence of tribal wānanga in New Zealand. Wānanga were a preEuropean phenomenon used to educate Māori tribal experts in the esoteric and specialised knowledge of their people, however, they have re-emerged as institutes of higher learning that focus primarily on Māori topics and learners and are part of the national process of Māori cultural revitalisation. Students who may once have enrolled in a university-based Māori studies programme now have the choice to instead study at wānanga (Smith 2002). Questions have already been raised about the future role of Māori studies since wānanga have re-cemented their role in educating Māori people. Walker (1999:195) was very clear that "it is not the business of Maori Studies to teach students how to be Maori" - implying that such work be left to tribal wānanga. Smith (2002:312) also asserted that wānanga were better placed to handle topics "too radical" for Māori studies in universities. So, within the search for threshold concepts, what are those elements of Māori scholarship to which a Māori studies discipline should be focused? And how can or should they be differentiated from what is being offered at wānanga? 


\section{Conclusion}

The idea of threshold concepts has been rapidly adopted since it emerged in 2005 and is informing SOTL research and practice across the world. This article sought, through the process of an integrative literature review, to synthesise what is already known about Māori studies as a discipline and find out whether threshold concepts could be applied in this context. What emerged were a number of questions and challenges, but also opportunities, to advance both threshold concepts theory and Māori studies as a discipline.

The current definition of threshold concepts is universal and quite broad. While this article has not sought to identify specific threshold concepts for Māori studies (as that is a task for future research) the range of questions that emerged from this review do generally fall within the key characteristics of threshold concepts.

Like threshold concepts, there are many aspects within the Māori studies discipline that are transformative. Māori studies is full of students who experience "both a cognitive and an ontological shift" (Land \& Meyer 2010:72) during the process of learning, due to the cultural and often deeply personal nature of the subject matter - but those experiences can be quite different for Māori students and non-Māori students, making it unlikely that their threshold concepts will be the same. The theory of threshold concepts does not appear to account for this kind of diversity. Part of the variation in student 'transformation' can be linked to their way of knowing. While Barradell and Peseta (2014) have already noted that threshold concepts can also relate to skills, attitudes and behaviours, the Māori studies example has shown that the transformation may also relate to their personal beliefs and values.

Another feature of threshold concepts is that they are likely to be irreversible. In relation to Māori studies, this article has explained how by turning Māori studies into a topic of study at university, the Māori knowledge has been irreversibly changed in order to make it knowable from Western epistemologies.

The integrative feature of threshold concepts is mirrored in Māori studies by the ways it draws on other disciplinary methodologies and methods and connects with other cultural and Indigenous studies programmes around the world. Similarly, the bounded nature of threshold concepts relates to how Māori studies has delineated a new field of study from other cognate disciplines. A question remains, however, about whether the multi-, inter- and transdisciplinary practices that are common within Māori studies will provide too much of challenge to threshold concepts theory.

Just like threshold concepts, some of the knowledge covered in Māori studies can be very troublesome to its students - although to some students more than others. The question remains, from whose perspective is the 'troublesomeness' measured? The kaupapa Māori approach favoured in Māori studies would centre the Māori students' experience, but the threshold concepts approach may favour the non-Māori majority.

The discursive element of threshold concepts seems more obscure than the other factors. In this article, however, it resonates with the idea of Māori studies (and the Māori culture) operating in a 
coded manner, with a formal curriculum that meets the requirements of the Western university and an invisible discourse based on Māori norms and values. Such a dual approach presents an added complication to the identification of Māori studies' threshold concepts.

Finally, the last characteristic of threshold concepts is liminality, the idea of crossing a border into new areas of understanding. This concept merges well with a theory from Indigenous studies about the cultural interface (Nakata 2007) but questions remain about the limits of this liminal space because, for Māori studies, threshold concepts may be used as a way to demarcate academic territory as much as clarify the curriculum.

Ultimately, Māori studies has thrown off many of the shackles of the "uncomfortable science" that was once unwelcome in the academy. That process will continue with further investigation into the possible threshold concepts of Māori studies, albeit with some modification of the threshold concepts theory to take account of the Māori studies context. Hopefully, such SOTL research work will support Māori studies as a discipline to emerge as the kōkako it was always meant to be.

Kōkako toko maunga e kore e rokohanga

A wattle bird flying up a mountain cannot be overtaken

\section{Acknowledgments}

The authors received funding for the wider project that has informed this article from Ngā Pae o Te Māramatanga, New Zealand's Māori Centre of Research Excellence.

\section{References}

Anderson, A, Binney, J \& Harris, A. 2014. Tangata Whenua: an Illustrated History. Wellington: Bridget William Books.

AUT. n.d. AUT timeline. [O]. Available:

http://www.aut.ac.nz/about-aut/aut-timeline

Accessed 12 April 2017.

Azam, MM. 2012. Threshold concept in intellectual property law. International Journal of Law and Management 58(4): 391-402.

Barradell, S \& Peseta, T. 2014. Promise and challenge of identifying threshold concepts: a cautionary account of using transactional curriculum inquiry. Journal of Further and Higher Education 42(2): 1-14.

Barrett, MJ, Harmin, M, Maracle, B, Patterson, M, Thomson, C, Flowers, M \& Bors, K. 2016. Shifting relations with the more-than-human: six threshold concepts for transformative sustainability learning. Environmental Education Research 23(1): 131-143. 
Biggs, B. 1978. Te whakaako i te reo Maaori i te Whare Waananga o Akarana. Talk given at interuniversity Māori Studies Conference, Wellington, New Zealand, 17-19 August 1978.

Cowart, MR. 2010. A Preliminary Framework for Isolating and Teaching Threshold Concepts in Philosophy, in Threshold Concepts and Transformational Learning, edited by R Land, JHF Meyer and C Baillie. Rotterdam: Sense Publishers: 131-145.

Dewes, T. 1975. The Case for Oral Arts, in Te Ao Hurihuri: the world moves on: aspects of Maoritanga, edited by M King. Wellington: Hicks Smith: 55-85.

Durie, M. 1996. The development of Maori studies in New Zealand universities. He Pukenga Kōrero 1(2): 21-32.

Durie, M. 2009. Towards social cohesion: the indigenisation of higher education in New Zealand. Vice Chancellor's Forum: how far are universities changing and shaping our world? Kuala Lumpur.

Education Counts. 2015. Profile \& Trends New Zealand's Annual Tertiary Education Enrolments 2014. Wellington: Ministry of Education.

Firth, S. 2003. Future directions for Pacific studies. The Contemporary Pacific 15(1): 139-148.

Gaudry, A. 2017. Indigenous studies is not a ghetto. [0]. Available: http://www.queensu.ca/connect/equity/2017/04/03/indigenous-studies-is-not-a-ghetto/ Accessed 12 April 2017.

Gurung, RAR \& Schwartz, BM. 2010. Riding the third wave of SoTL. International Journal for the Scholarship of Teaching and Learning 4(2): 1-6.

Hall, M, Rata, A \& Adds, P. 2013. He manu hou: the transition of Māori students into Māori Studies. The International Indigenous Policy Journal 4(4): 1-19.

Hanson, A. 1989. The making of the Maori: culture invention and its logic. American Anthropologist, 91(4): 890-902.

Ka`ai, T. 2000. Ngā hua o te mātauranga Māori i roto i te whare wānanga: the value of Māori Studies in the university. Inaugural professorial lecture, Dunedin, New Zealand, 19 July 2000.

Khan, RN. 2014. Identifying Threshold Concepts in First-Year Statistics. Educational Research and Perspectives 41: 217-231.

Land, R \& Meyer, JHF. 2010. Threshold Concepts and Troublesome Knowledge (5): Dynamic of Assessment, in Threshold concepts and transformational learning, edited by JHF Meyer, $\mathrm{R}$ Land and C Baillie, C. Rotterdam: Sense Publishers: 303-316.

Levett-Jones, T, Bowen, L \& Morris, A. 2014. Enhancing nursing students' understanding of threshold concepts through the use of digital stories and a virtual community called 'Wiimali'. Nurse Education in Practice 15: 91-96.

McLean, J. 2009. Triggering engagement in SoTL through threshold concepts. International Journal for the Scholarship of Teaching and Learning 3(2): 1-5. 
Mead, SM. 1983. Te toi mātauranga Māori mo ngā rā kei mua: Māori studies tomorrow. The Journal of the Polynesian Society 92(3): 333-351.

Mead, SM. 1997. Māori studies in the universities in the 1990s, in Landmarks, bridges and visions: aspects of Maori culture: essays. Wellington: Victoria University Press: 39-49.

Mercier, OR, Asmar, C \& Page, S. 2011. An academic occupation: mobilisation, sit-in, speaking out and confrontation in the experiences of Māori academics. The Australian Journal of Indigenous Education 40: 81-91.

Mercier, OR, Douglas, SL, McFadgen, B, Hall, M, Adds, P, Bargh, M \& Wilson, T. 2013. Promoting engagement through a student-built digital atlas of Maori studies, in increasing student engagement and retention using multimedia technologies: video annotation, multimedia applications, videoconferencing and transmedia storytelling. Emerald Group Publishing: 121158.

Meyer, J \& Land, R. 2006. Overcoming barriers to student understanding: threshold concepts and troublesome knowledge. London \& New York: Routledge.

Nakata, M. 2006. Australian Indigenous studies: a question of discipline. The Australian Journal of Anthropology 17(3): 265-275.

Nakata, M. 2007. The cultural interface. Australian Journal of Indigenous Education 36: 7-14.

O'Brien, M. 2008. Navigating the SoTL Landscape: a compass, map and some tools for getting started. International Journal for the Scholarship of Teaching and Learning 2(2): 1-20.

Openshaw, R. 2006. Putting ethnicity into policy: a New Zealand case study, in Public policy and ethnicity: the politics of ethnic boundary-making, edited by E Rata. London: Palgrave Macmillan: 113-127.

Page, S. 2014a. Exploring new conceptualisations of old problems: researching and reorienting teaching in Indigenous studies to transform student learning. Australian Journal of Indigenous Education 43(1): 21-30.

Page, S. 2014b. Intersecting and overlapping spaces: combining teacher and student perspectives to identify threshold concepts in Indigenous Australian Studies. Fifth International Biennial Threshold Concepts conference, Threshold Concepts in Practice, Durham, United Kingdom, 9-11 July 2014.

Page S. 2015. Theoretical learning spaces: exploring threshold concepts, the cultural interface and the zone of proximal development to better understand student learning in Indigenous Studies. Indigenous Content in Education Symposium, Adelaide, Australia, 21 September 2015.

Page, S. 2016. Using the Threshold Concepts Framework to research student resistance; a common dilemma in Indigenous Studies. Sixth International Biennial Threshold Concepts Conference, Thresholds on the Edge. Dalhousie University, Halifax, Nova Scotia, Canada, 15-17 June 2016. 
Pohatu, G. 1998. The university, Maori studies and the Treaty praxis. Unpublished PhD dissertation, The University of Otago, Dunedin, New Zealand.

Reilly, MP. 1996. Entangled in Māori history: a report on experience. The Contemporary Pacific 8(2): 388-408.

Reilly, M. 2008. What is Māori Studies? Lecture presentation, University of Otago, Dunedin, New Zealand. [O]. Available: https://ourarchive.otago.ac.nz/bitstream/handle/10523/5159/Reilly 1.pdf?sequence=4\&isA llowed $=\mathrm{y}$ Accessed 22 March 2017.

Reilly, MPJ. 2011. Māori studies, past and present: a review. The Contemporary Pacific 23(2): 340369.

Rowbottom, DP. 2007. Demystifying threshold concepts. Journal of Philosophy of Education 41(2): 263-270.

Royal, T. 2012. Politics and knowledge: Kaupapa Maori and matauranga Maori. New Zealand Journal of Educational Studies 47(2): 30-37.

Salmond, A. 1983. The study of traditional Maori society: the state of the art. The Journal of the Polynesian Society 92(3): 309-331.

Salmond, A. 2003. Self and other in contemporary anthropology, in Counterworks: managing the diversity of knowledge, edited by R Fardon. London \& New York: Routledge: 23-49.

Simmons, N, Abrahamson, E, Deshler, JM, Kensington-Miller, B, Manarin, K, Morón-García, S, Oliver, C \& Renc-Roe, J. 2013. Conflicts and configurations in a liminal space: SoTL scholars' identity development. Teaching and Learning Inquiry: The ISSOTL Journal 1(2): 9-21.

Sissons, J. 1995. Tall trees need deep roots: biculturalism, bureaucracy and tribal democracy in Aotearoa/New Zealand. Cultural Studies 9(1): 61-73.

Smith, CW. 2000. Straying beyond the boundaries of belief: Maori epistemologies inside the curriculum. Educational Philosophy and Theory 32(1): 43-51.

Smith, CW. 2002. He pou herenga ki te nui: Maori knowledge and the university. Unpublished PhD dissertation. The University of Auckland, Auckland, New Zealand.

Snepvangers, K \& Bulger, J. 2016. Learning in liminal spaces: encountering Indigenous Knowledge and Artworks in Professional Education. Fusion Journal 8: 1-23.

Sorrenson, K. 1986. Na tou hoa aroha 1. Auckland: Auckland University Press.

Statistics New Zealand. 2015. New Zealand Census 2013: Major ethnic groups in New Zealand. Wellington: Statistics New Zealand.

Stewart-Harawira, M. 2013. Challenging knowledge capitalism: Indigenous research in the 21st century. Socialist Studies 9(1): 39-51. 
Talanquer, V. 2015. Threshold concepts in chemistry: the critical role of implicit schemas. Journal of Chemical Education 92(1): 3-9.

Teaiwa, T. 2001. L(o)osing the edge. The Contemporary Pacific 13(2): 343-365.

Te Huia, A. 2016. He tirohanga hou: emotional responses to learning about the colonisation of Aotearoa. Ngā Pae o te Māramatanga International Indigenous Research conference, Auckland, New Zealand, 15-18 November 2016.

Timms, CE. 2007. Whāia te māramatanga: Māori language revitalisation and tertiary education in Aotearoa. MAI Review (1), Article 2.

Torraco, RJ. 2005. Writing integrative literature reviews: guidelines and examples. Human resource development review 4(3): 356-367.

USC 2016. A Framework for Embedding Aboriginal Knowledges and Perspectives and Torres Strait Islander Knowledges and Perspectives in Curriculum at USC. University of the Sunshine Coast (USC). [O]. Available:

http://www.usc.edu.au/media/19138386/embedding-framework-dec16-pdf-version.pdf Accessed 12 April 2017.

Walker, R. 1999. The development of Maori studies in tertiary education in Aotearoa/New Zealand. In After the disciplines: the emergence of cultural studies, edited by M Peters. Westport, Conn.: Bergin \& Garvey: 187-198.

Webb, AS. 2016. Threshold concepts and the Scholarship of Teaching and Learning, in Threshold Concepts in Practice edited by R Land, JHF Meyer and M Flanagan. The Netherlands: Sense Publishers: 299-308.

Webster, S. 1993. Postmodernist theory and the sublimation of Maori culture. Oceania 63(3): 222239.

Webster, S. 1998. Patrons of Māori culture: power, theory and ideology in the Māori renaissance. Dunedin: University of Otago Press. 